\title{
INCREASING THE EFFICIENCY OF LOGISTICS FLOW IN PRODUCTION SYSTEM BY THE SOFTWARE TOOL TECNOMATIX PROCESS SIMULATE
}

\author{
$1^{\text {st }}$ Peter Trebuňa ${ }^{1}, 2^{\text {nd }}$ Miriam Pekarčíková ${ }^{2}, 3^{\text {rd }}$ Oleksandr Liaposhchenko ${ }^{3}, 4^{\text {th }}$ Marián \\ Petrik $^{4}$ \\ \{peter.trebuna@tuke.sk ${ }^{1}$, miriam.pekarcikova@tuke.sk ${ }^{2}$, \\ lyaposchenko@pohnp.sumdu.edu.ua ${ }^{3}$, marian.petrik@tuke.sk ${ }^{4}$ \}
}

\begin{abstract}
Technical University in Kosice, Faculty of Mechanical Engineering, Institute of Management, Industrial and Digital Engineering, Park Komenského 9, 04200 Košice, Slovakia ${ }^{1}$, Technical University in Kosice, Faculty of Mechanical Engineering, Institute of Management, Industrial and Digital Engineering, Park Komenského 9, 04200 Košice, Slovakia ${ }^{2}$ Department of Processes and Equipment of Chemical and Petroleum-Refineries, Sumy State University, 2, Rymskogo-Korsakova st., 40007 Sumy, Ukraine $^{3}$, Technical University in Kosice, Faculty of Mechanical Engineering, Institute of Management, Industrial and Digital Engineering, Park Komenského 9, 04200 Košice, Slovakia $^{4}$
\end{abstract}

\begin{abstract}
Basic tool for increasing business process efficiency in the context of Industry 4.0 is to create a Digital Twin. Using the PLM/Product Lifecycle Management tools it is possible to create a digital business model, capture data from the manufacturing process, evaluate and continually optimize processes and subsequently returned them to physical production. In the context of the above, the article is focuses to problems of introduction of digitization of logistics processes through support software module Tecnomatix Process Simulate. The aim was increase the logistics flow efficiency in selected company using software tool Tecnomatix Process Simulate. The application of an appropriate simulation tool will enable to increase the possibilities of finding lean solutions, selecting and implementing the optimum solution to the real system. Case study illustrates potential that can be achieved by the way of modelling and simulation the real production system.
\end{abstract}

Keywords: optimization, logistics, simulation, modelling, process.

\section{Introduction}

Tecnomatix Process Simulate is one of Siemens' Tecnomatix software packages that include the entire Product Lifecycle Management/PLM from product development through production planning, logistics and ergonomics (RobCAD, FactoryCAD, FactoryFlow, Plant Simulation, Process Designer, Jack and Jill). With the help of this software, it is possible to create kinematic 3D simulations, dynamic and static collision detection, 2D and 3D sections, 3D measurements, operation management, resource modelling, 3D workstation design, automatic assembly planning, simulation of human movement, etc. 1 [1], [2], [3], [4]. Moreover, enables connecting the physical components of the industrial automation directly to the simulation environment, it is also possible to realistically test the functionality of the 
prepared program for a control unit/PLC and set and map the signals. Tecnomatix Process Simulate enables virtually to launch, revive, and test the proposed solution [5], [6], [7], [8].

Below listed case study illustrates optimization of logistics flows using TX Process Simulate software. Modelling and simulation of workplace in a software module Process Simulate enables to rationalize it in virtual environment, which will contribute to cost savings which would have been spent in the process of direct implementation of the proposals in practice. Effective use of simulation tools requires an accurate analysis of initial state. This will provide input for creation a model and implementation of simulation. [9], [10], [11], [12]. This study does not interpret all realized analysis, but is focused on the interpretation of the realised simulation. Diagram in Figure 1, shows a recommended workflow for executing a simulation study. The first step is to set goals and effective ways to measure the results of the model. Thanks to that it is easier to build an accurate model. While modelling, it is necessary to determine the factors that affect the results of the model and eliminate the factors that can be ignored. Next, the validation follows. If the model meets the criteria then experiments can be made. The advantage is that experiments will show many possibilities which can be executed before any changes are recommended for the real system. [13], [14], [15], [16]. When creating a simulation, avoid errors that can lead to incorrect results [17], [18], [19], [20], [21]:

- inaccurate specifications and parameters,

- $\quad$ an inaccurate goal or none at all,

- a missing or inaccurate definition of how to measure the results of the model,

- a model that is too detailed and complicated and is hard to understand,

- a model that is too abstract,

- an insufficiently validated model,

- incorrect assumptions.

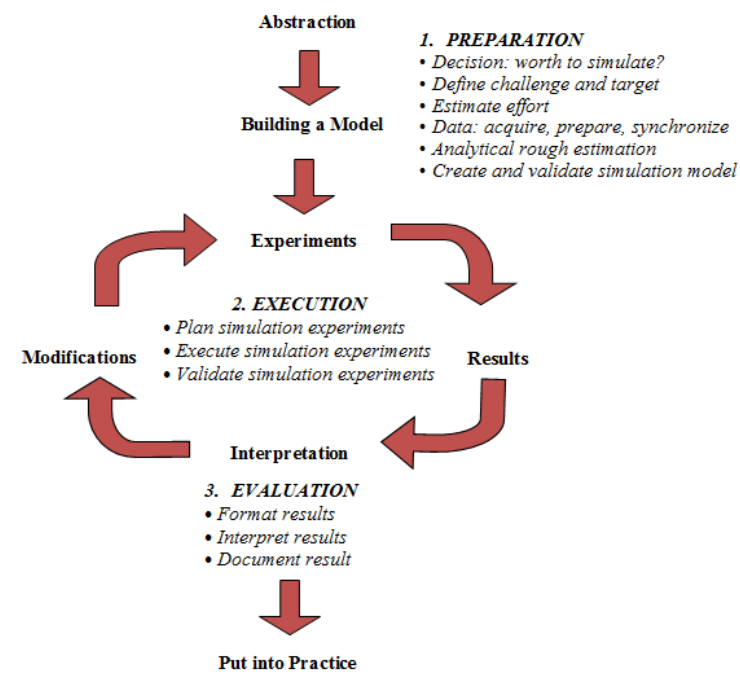


Fig. 1. Basic Simulation Work Flow

\section{Case study of implementation Tecnomatix Process Simulate}

Selected company operates in the production of bearing houses and clevises designed for rail vehicles, machining of castings, welding of subgroups for rail vehicles and production of double-wheel angular saws type UPK 1000. One of the reasons for optimization the workplace is to eliminate unproductive time to productive by implementation of new production of axle box and reducing unnecessary handling direct staff. The company is currently one of the most important Slovak producers of axle boxes, as shown in Figure 2 and clevis designed for rail vehicles. It is also a long-time producer of circular angular saw for processing logs and hydraulic cranes used for handling loads.

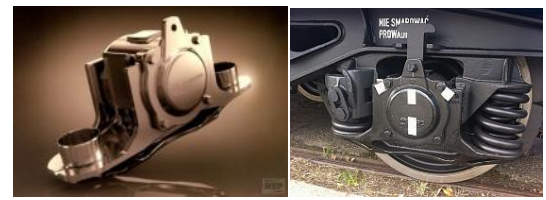

Fig. 2. Bearing housing, Bearing housing

The original of logistic company flow is modelled in software module Tecnomatix Process Simulate, as shown in Figure 3. There are defined individual steps of moving products in the workplace, where the beginning of flow is in point one in the warehouse with the original (unadjusted) products. Logistics flow begins by moving products from the warehouse to the conventional beam house which is in point 2 . Then the worker unloads variety of products in the workshop and takes balanced pieces into the buffer stock in point 3 . In this stock there are always stored several pallets of flat products which are ready for further processing. Worker takes away these pieces to CNC machining centres where the process of machining is in progress. Forasmuch as the company manufactures products in three sets of simple clevises and one squab by clevis, worker is required to bring to one centre 1 palette of simple clevises and to second centre 1 palette of squab by clevises. Then he takes finished pieces on pallets from these two centres one after the other and he takes them to the dispatch warehouse. This original logistic flow seems to be very complicated. The original times of operations and handling workers were measured and they were registered in working day shots. The proposed solution of optimizing production is modification in the logistics flow, dispositional layout of workplace and expansion of production by axle boxes of type BA 382 . It leads to shortening of handling times, increasing of production and reducing of downtime of CNC machines and workers. 


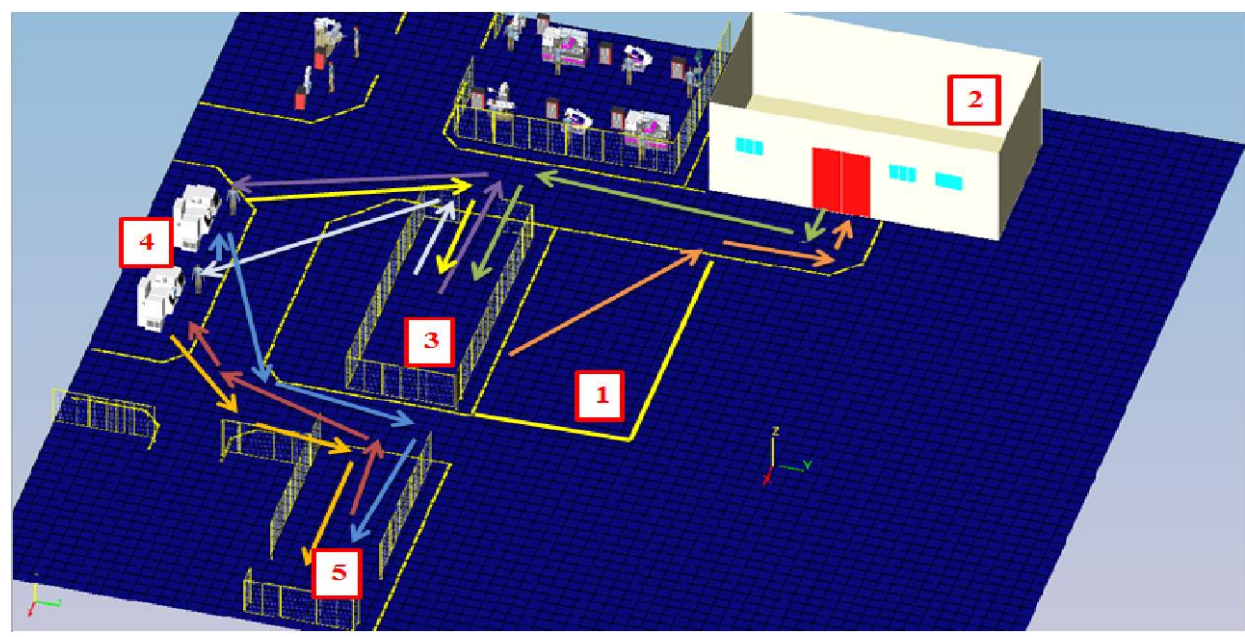

Fig. 3. The original logistics flow of company

The working process takes place in five consecutive operations, concretely:

- burning - removal of unwanted parts of clevises,

- $\quad$ grinding of parts where unwanted parts were removed,

- $\quad$ piling (flexing) process.

By thermal intervention to clevises, the individual pieces are hooped. The workers perform process of measurement and straightening on hydraulic machines in manufactory where the first two operations are in progress. Company produces simple and squab by clevises. It means that workers must pay attention to what kind of clevis they work with. Working of both pieces of clevis requires the same time. Measured times for individual work stages are followed: Burning: 1.30 min., Grinding: 3.17 min., Straightening: 4.15 min. Pieces that undergone the various operations are separately carried away by direct staff to the buffer stock. Then he takes these pieces away separately to CNC machining centres. Two operations of processing prepared pieces from conventional workshop are in progress there. At this point it is necessary to different types of machined piece. Simple clevises are machined on one CNC machine and squab by clevises are machined on the other one. The operations mentioned above were measured in the following values:

- Simple clevis: 1 st operation: 15,2 min., 2nd operation: 13,0 min.

- Squabby clevis: 1 st operation: $15,5 \mathrm{~min} ., 2$ nd operation: $13,5 \mathrm{~min}$.

It follows that total time for production one piece of simple clevis is $36,8 \mathrm{~min}$. and the time for production one piece of squab by clevis is $37,6 \mathrm{~min}$. This is a productive machine time for one piece. So the company per day (working shift/11,5 hours) will produce 18,75 pieces of simple clevises and 18,35 pieces of squab by clevises. The contract is completed in set: 3 pieces of simple clevis +1 piece of squab by clevis. Logistics flow starts before the buffer stock. The direct staffs take pieces into a conventional workshop for the working process of first three stages of production. The direct staff must distinguish which part of clevis will be moved to conventional workshop. Then he brings finished pieces into the buffer stock and he stores them systematically to each other. Simple clevises are stored on the one hand and squab by clevises are on the other hand. Direct staff than bring prepared pieces to $\mathrm{CNC}$ machining centres, where individual pieces are wrought to the final form.

Simple clevises are wrought just at one machining centre and squab by clevises on the other one. In the original scheme, we can see a lot of rotations and handlings of one worker 
with individual pieces in warehouse and at the workplace. In measured values it indicates lengthy handling. Transport of pallets in warehouse from the first handling of original pieces, to removal of prepared pallets of four pieces to $\mathrm{CNC}$ machining centres and subsequently despatch to store lasts 29 minutes and 20 seconds. This measured time is labelled as processing time. Thus, it is the time which indirectly adds some value to the product. Movements and material handling are shown in Figure 4 and creation of human motion is shown in Figure 5. Creating and working with the Process Simulate software was the most used MODELING, HUMAN and OPERATIONS. Some parts of the workplace were drawn in the SOLIDWORKS and INVENTOR program. These are models of conventional workshop and models of simple and squabby clevises. These models were converted to .jt, which is supported by the software. The measured and processed values are shown in Figure 6 a), b), c). Proposed solutions for optimization the workplace was implemented into the practice and the company achieved the increase in production, shown in Figure 7. We proposed dispositional layout of workplace, it means elimination of buffer stock in result of which handling times of direct staff are shortened. We also suggested production of axle box BA 382 , which is actually also part of the wagon chassis. This order can be drawn from subsidiary company which cannot produce this kind of assortment. These axle boxes are designed to be produced on a CNC machine where squab by clevises are produced. This would increase the production of the spare machine and downtime of workers and centre would decrease.

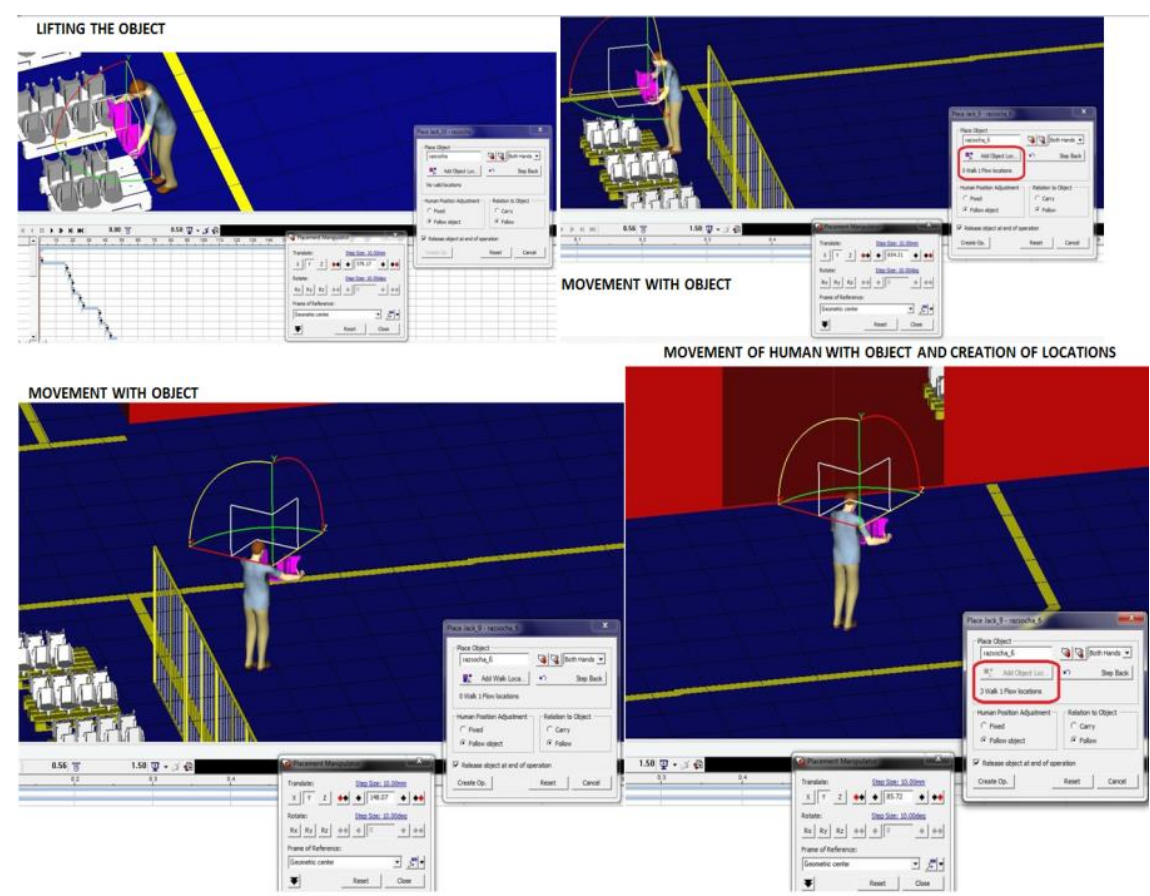

Fig. 4. Movements and material handling of worker 


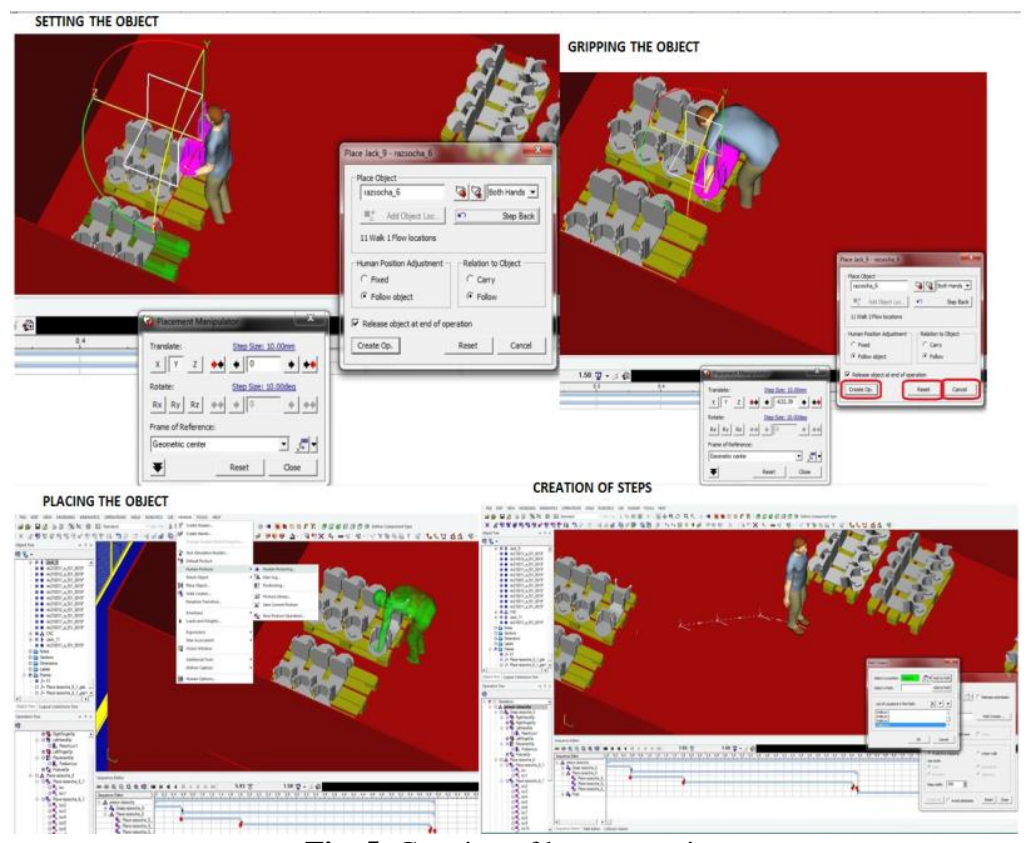

Fig. 5. Creation of human motion

Implementation and production on this CNC machine would not be a problem, seeing that company owns machines that are capable to produce several pieces in two different programs. Reducing the downtime of the operator serving the machining centre and shortening the time of the directional worker is documented by the working day shot, as shown in Figure 8 and Figure 9. This is own processing (MS Excel) of the measured values in company. 


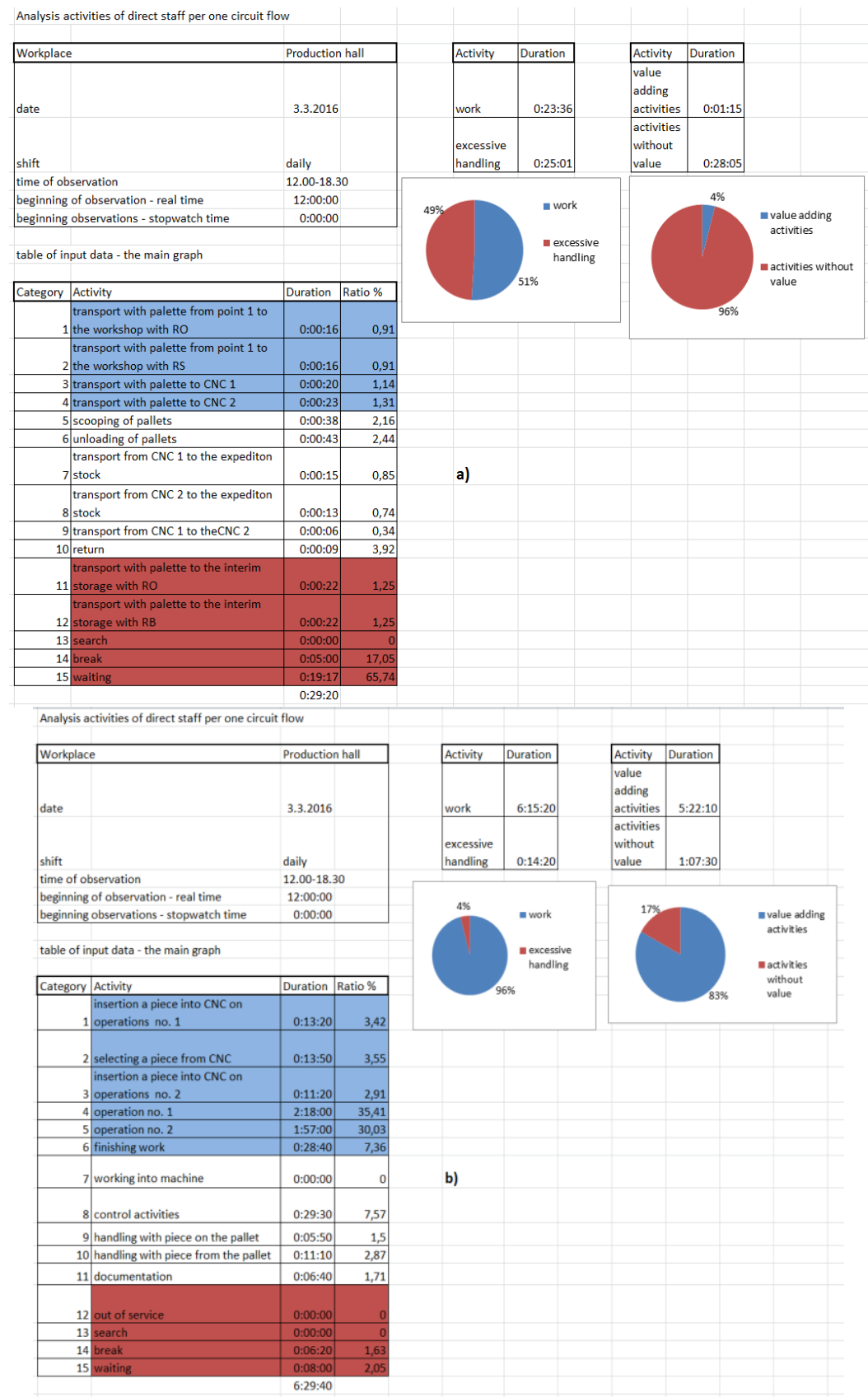


Analysis activities of direct staft per one circuit flow

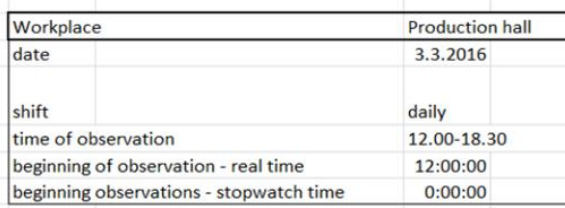

\begin{tabular}{|l|r|}
\hline Activity & Duration \\
\hline work & $3: 31: 00$ \\
\hline excessive & \\
\hline
\end{tabular}

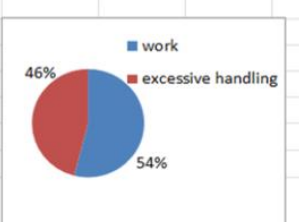

\begin{tabular}{|c|c|c|c|}
\hline Category & Activity & Duration & Ratio \% \\
\hline & $\begin{array}{l}\text { insertion a piece into CNC on } \\
\text { operations no. } 1\end{array}$ & $0: 10: 20$ & 2,65 \\
\hline 2 & 2 selecting a piece from $\mathrm{CNC}$ & $0: 16: 20$ & 4,19 \\
\hline & $\begin{array}{l}\text { insertion a piece into } \mathrm{CNC} \text { on } \\
\text { operations no. } 2\end{array}$ & $0: 08: 20$ & 2,14 \\
\hline & operation no. 1 & $0: 46: 30$ & 11,93 \\
\hline 5 & operation no. 2 & $0: 41: 30$ & 10,65 \\
\hline 6 & 5 finishing work & $0: 15: 50$ & 4,06 \\
\hline & working into machine & $0: 24: 50$ & 6,37 \\
\hline & control activities & $0: 20: 30$ & 5,26 \\
\hline 9 & handling with piece on the pallet & 0:07:10 & 1,84 \\
\hline 10 & handling with piece from the pallet & $0: 09: 10$ & 2,35 \\
\hline 11 & 1 documentation & $0: 10: 30$ & 2,69 \\
\hline 12 & 2 out of service & $0: 00: 00$ & 0 \\
\hline 13 & 3 search & $0: 00: 00$ & 0 \\
\hline 14 & 4 break & $2: 50: 40$ & 43,8 \\
\hline 15 & 5 waiting & 0:08:00 & 2,05 \\
\hline
\end{tabular}

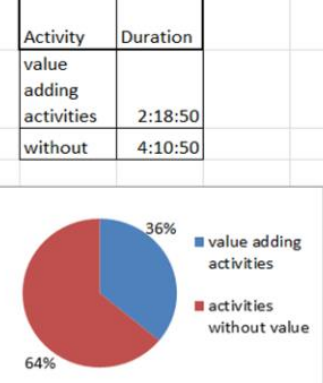

c)

Fig.6. Measured and processed values a) direct worker b) operator of CNC machines - normal clevis c) operator of CNC machines - squab by clevis

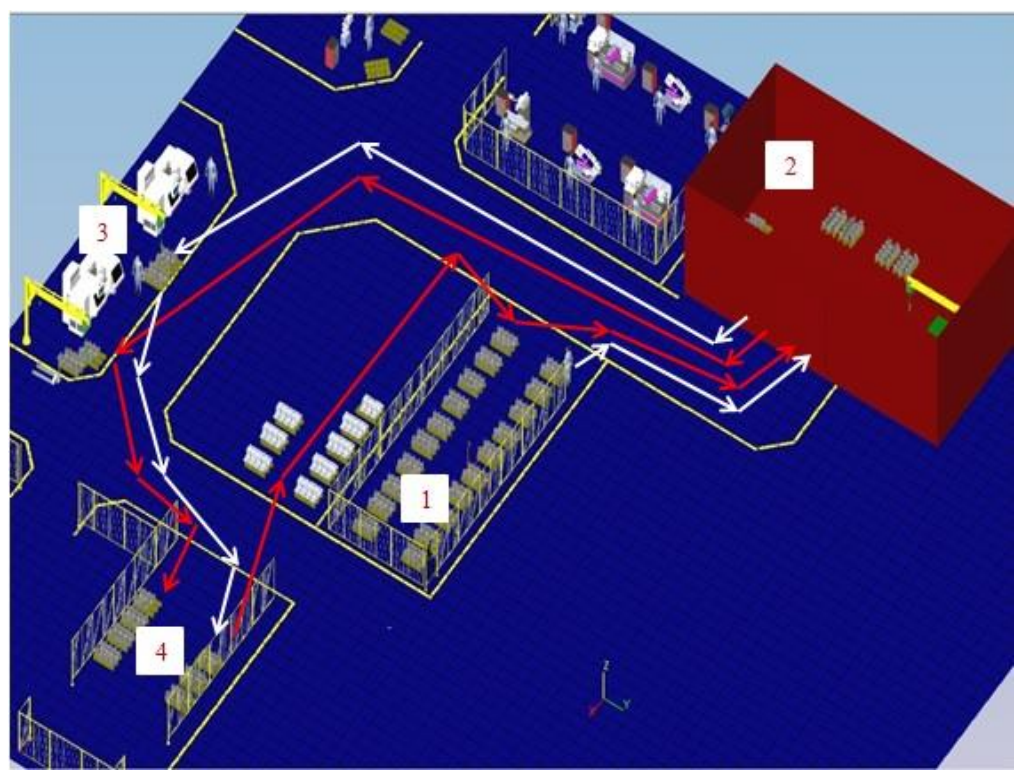

Fig.7. Suggested logistics flow 


\begin{tabular}{|c|c|c|c|c|c|}
\hline \multicolumn{2}{|c|}{ Workplace } & \multicolumn{2}{|c|}{ Production hall } & Activity & Duration \\
\hline date & & \multicolumn{2}{|l|}{3.3 .2016} & work & 0:11:01 \\
\hline shift & & \multicolumn{2}{|l|}{ daily } & excessive handling & 0:05:00 \\
\hline \multicolumn{2}{|c|}{ time of observation } & \multicolumn{2}{|c|}{$12.00-18.30$} & & \multirow{6}{*}{$\begin{array}{l}\text { Iexcessive } \\
\text { handling }\end{array}$} \\
\hline \multicolumn{2}{|c|}{ beginning of observation - real time } & \multicolumn{2}{|l|}{$12: 00: 00$} & & \\
\hline \multicolumn{2}{|c|}{ beginning observations - stopwatch time } & \multicolumn{2}{|l|}{$0: 00: 00$} & & \\
\hline \multicolumn{4}{|c|}{ table of input data - the main graph } & & \\
\hline \multirow{2}{*}{$\begin{array}{r}\text { Category } \\
1 \\
1\end{array}$} & Activity & \multicolumn{2}{|c|}{ Duration Ratio \% } & & \\
\hline & $\begin{array}{l}\text { transport with palette from point } 1 \text { to the } \\
1 \text { workshop with RO }\end{array}$ & $0: 00: 16$ & 1,66 & & \\
\hline \multicolumn{2}{|r|}{ transport with palette from point 1 to the } & $0: 00: 15$ & 1,56 & Activity & Duration \\
\hline \multicolumn{2}{|r|}{3 transport with palette to CNC1 } & $0: 00: 22$ & 2,29 & value adding activities & $0: 01: 17$ \\
\hline \multicolumn{2}{|r|}{4 transport with palette to CNC2 } & $0: 00: 24$ & 2,5 & activities without value & $0: 06: 44$ \\
\hline \multicolumn{2}{|r|}{5 scooping of pallets } & $0: 00: 27$ & 2,81 & & \multirow{8}{*}{$\begin{array}{l}\text { Ivalue adding } \\
\text { activities } \\
\text { activities } \\
\text { without value }\end{array}$} \\
\hline \multicolumn{2}{|r|}{6 unloading of pallets } & $0: 00: 29$ & 3,02 & & \\
\hline & 7 transport from CNC 1 to the expediton stock & $0: 00: 15$ & 1,56 & & \\
\hline & 8 transport from CNC 2 to the expediton stock & $0: 00: 13$ & 1,35 & & \\
\hline & 9 transport from CNC 1 to the CNC2 & 0:00:00 & 0 & & \\
\hline & 0 return & $0: 00: 20$ & 2,08 & & \\
\hline \multirow{2}{*}{\multicolumn{2}{|c|}{15 waiting }} & 0:05:00 & 31,22 & & \\
\hline & & \multicolumn{2}{|l|}{$0: 16: 01$} & & \\
\hline
\end{tabular}

Fig.9. Proposed usability of the directional worker

\section{Conclusion}

Digitization is applied in various industries. Even through the Tecnomatix Process Simulate tool can move the entire enterprise value chain to a higher level. Exact digital modelling, simulation and 3D spatial visualization allow professionals who collaborate to each other, to develop, visualize and analyse future production processes. Such an assessment will enable key decisions to be implemented and agreed in time, even on the basis of a wider understanding. This reduces errors that would otherwise arise only when the production started. In case study applied module Tecnomatix Process Simulate has enabled to create a comprehensive and realistic view of the production process through a fairly detailed simulation of logistics material flow with simulation of human movement. Applying simulation software which involves whole life cycle of products creates the conditions for quality communication of every member of the value chain anywhere and in real time. Technologists are able to provide the constructor with immediate feedback on whether there are any limitations on manufacturability. Such collaboration between individual chain members creates a comprehensive view of production planning and processes in the Industry 4.0 context. In the near future, it becomes important to fully connect the real environment with the digital environment through individual elements that are known in the context of Industry 4.0, for example, CPS, big data, cloud computing, IoT, IoS, etc. As part of this system, will be today used software products, like Tecnomatix Process Simulate, which is mentioned in the article. The implementation of these elements will allow for the creation of so-called Digital twin, which enable to implement, test and implement real-time changes, which will represent 
the next level of company digitization, which will be an object of interest in our further research.

Acknowledgement. This article was created by implementation of the grant project VEGA 1/0708/16 Development of a new research methods for simulation, assessment, evaluation and quantification of advanced methods of production, KEGA 030TUKE-4/2017 Implementation of innovative instruments for increasing the quality of higher education in the 5.2.52 Industrial engineering field of study, APVV-17-0258 Digital engineering elements application in innovation and optimization of production flows

\section{References}

[1] Centobelli, P., Cerchione, R., Murino, T. Gallo, M.: Layout and material flow optimization in digital factory. International Journal of Simulation Modelling, Vol. 15, pp. 223-235. (2016)

[2] Straka, M.; Malindzakova, M., Trebuna, P., Rosova, A., Pekarcikova, M., Fill, M.: Application of EXTENDSIM for improvement of production logistics' efficiency, International Journal of Simulation Modelling, Vol. 16, pp. 422-434, doi:10.2507/IJSIMM16(3)5.38. (2017)

[3] Lenort, R., Stas, D., Samolejova, A.: Heuristic Algorithm for Planning and Scheduling of Forged Pieces Heat Treatment, Metalurgija, Vol. 51, pp. 225-228. (2012)

[4] Xiao, N., Ni, C. D., Guo, S. J.: Modelling and simulation for production logistics system in industrial enterprises based on hybrid network, International Journal of Simulation Modelling, Vol. 16, pp. 157-166. (2017).

[5] Siemens. Tecnomatix. Retrieved 16 September, 2017, from http://www.sova.sk/sk/produkty/tecnomatix, (2017)

[6] Siemens. Process Simulate: Manufacturing process verification in powerful 3D environment. $\quad$ Retrieved 11 January, $2018, \quad$ from https://www.plm.automation.siemens.com/en/products/tecnomatix/manufacturingsimulation/robotics/process-

simulate.shtml\#lightview\%26url=/en_us/Images/7457_tcm1023-

80351.pdf\%26title=Process Simulate\%26description=Process Simulate Fact Sheet $\% 26$ docType=pdf. (2018)

[7] Seebacher, G., Winkler, H., Oberegger, B.: In-plant logistics efficiency valuation using discrete event simulation, International Journal of Simulation Modelling, Vol. 14, pp. 6070. doi:10.2507/IJSIMM14(1)6.289. (2015).

[8] Centobelli, P., Cerchione, R., Murino, T., Gallo, M.: Layout and material flow optimization in digital factory, International Journal of Simulation Modelling, Vol. 15, pp. 223-235. doi:10.2507/IJSIMM15(2)3.327. (2016).

[9] Edl M., Kudrna, J.: Methods of industrial engineering. 1nd. ed. Smart Motion, Plzen, Czech Republic. (2013)

[10] Laciak, M., Sofranko, M.: Designing of the technological line in the SCADA system PROMOTIC, Proceedings of the 2013 14th International Carpathian Control Conference, Rytro, Poland. (2013)

[11] Malindzakova, M., Rosova, A., Baranova, V., Futo, J.: Modelling of outbursts and ejections occurrences during steel production, Metalurgija, Vol. 54, pp. 247-250. (2015)

[12] Saniuk, S., Saniuk, A., Lenort, R., Samolejova, A.: Formation and planning of virtual production networks in metallurgical clusters, Metalurgija, Vol. 53, pp. 725-727. (2014). 
[13] Straka, M., Bindzar, P., Kadukova, A.: Utilization of the multicriteria decision-making methods for the needs of mining industry, Acta Montanistica Slovaca, Vol. 19, pp. 199206. (2014).

[14] Straka, M.: Simulation of Discrete Systems and Simulation Languages, 1nd. ed. TU Kosice, Kosice, Slovak Republic. (2005).

[15] Badida, M., Gombar, M., Maslejova, A., Sobotova, L., Kmec, J., Vagaska, A.: Evaluation of zinc coating quality by statistical methods, Przemysl Chemiczny. Vol. 94, pp. 2146-2149, doi.:10.15199/62.2015.12.11. (2015).

[16] Straka, M.: Alfa, a.s. distribution logistics system, Acta Montanistica Slovaca, Vol. 15, pp. 34-43. (2010)

[17] Gub'an M., Kov'acs G., Kot S., Simulation of complex logistical service processes, Management and Production Engineering Review, Vol. 8, pp. 19-29- (2017)

[18] Zawadzki P., Zywicky K., Smart product design and production control for effective mass customization in the Industry 4.0 concept, Management and Production Engineering Review, Vol 7,pp. 105-112. (2016)

[19] Klos S., Ptalas-Maliszewska, J.: The impact of ERP on maintenance management, Management and Production Engineering Review, Vol. 4, pp. 15-25. (2013)

[20] Madzík, P., Chocholáková, A., Čarnogurský, K., Droppa, M., Lysá, L': Is quality a philosophy or rather a mind-set? In: Quality - Access to Success. - ISSN 1582-2559, Vol. 18, Issue 161 (2017), p. 116-125

[21] Madzík, P., Čarnogurský, K., Diačiková, A.: Consumer feedback - how relevant is it for quality improvement? In: Marketing Identity: Digital Life - part II.: Conference Proceedings from International Scientific Conference 10th - 11th November 2015, Congress Hall of the Slovak Academy of Sciences, Smolenice, Slovak Republic, 1. vyd. Trnava: Faculty of Mass Media Communication, University of Ss. Cyril and Methodius in Trnava, 2015. p. 148-159. 